\title{
Oil Can Make A Difference: Collaborating With NGOs In Azerbaijan
}

Roger Alan Ritvo, Auburn University Montgomery, USA

\begin{abstract}
This study reports the findings from a 2006-2007 research project of non-governmental organizations (NGOs) in Azerbaijan. There is reason to believe that the changes in Azerbaijan's economy because of oil in the Caspian Sea will spur added growth of NGOs and be a catalyst for an expanded civil society, if only because of the international attention that such development brings. As an integral part of the development of a civil society, NGOs serve a special mediating role between the government and the population and they can be important forces for change. They can fill service and program gaps and meet local needs when government is unwilling or unable to do so. Using principles for the development of civil societies, the NGOs in Azerbaijan are slowly making progress. Current practices were documented through interviews conducted by the author, literature reviews, correspondence and record review. There are serious concerns that international businesses must be aware of when doing business in Azerbaijan and forming mutually beneficial partnerships with NGOs.
\end{abstract}

Keywords: Azerbaijan; NGOs; Nonprofit organizations; Civil Societies

\section{INTRODUCTION}

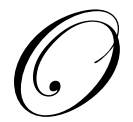

il revenues continue to increase in Azerbaijan. In the first 6 months of 2009, production increased almost 3\%, to a million barrels per day as compared to a year earlier (Wall Street Journal, 2009). With this ticket into the global economy and a pipeline from Azerbaijan to the Mediterranean Sea, international attention and commerce have increased, sometimes to the embarrassment of the government. This article defines how international corporations can, and should, partner with nongovernmental organizations (NGOs) in this emerging post-Soviet country. Internationally, Azeri consultants have been in discussions with officials in Havana, Cuba, to share expertise in oil production (Rianovosti, 2009), yet all is not running smoothly. A recent headline proclaimed "Stealth Oil Agreements Threaten Azerbaijan's Reputation and Policy Progress" (Publishwhatyoupay.com, 2009).

Starting a new business in Azerbaijan is one of the real changes that has occurred in recent years. According to the World Bank (2008), "doing business" is becoming much easier in this emerging democracy of 8.6 million people. Table 1 shows dramatic improvement and is part of a new attitude toward business and the private sector.

Table 1: Starting A New Business In Azerbaijan

\begin{tabular}{|l|c|c|c|}
\hline \multicolumn{1}{|c|}{ Starting A Business } & $\mathbf{2 0 0 7}$ & $\mathbf{2 0 0 8}$ & $\mathbf{2 0 0 9}$ \\
\hline Rank (out of 181 countries) & 128 & 66 & 11 \\
\hline Required Procedures & 14 & 13 & 6 \\
\hline Expected Days to Process (days) & 52 & 30 & 16 \\
\hline
\end{tabular}

As more firms move into this rapidly expanding country, they may be asked to develop partnerships with domestic NGOs. There are many reasons for doing so. First, a firm may see it as being in its strategic business interest to connect with local NGOs. An example would be the oil companies (led by BP) developing scholarships and funding research at the world-famous Oil Academy in the capital city of Baku. Since petroleum fuels their 
corporate profits, energy-related philanthropy is in a firm's economic interest. Alternatively, the firm may chose to connect with NGOs as part of its broader corporate image. Thus, when Halliburton provides funding to the national symphony orchestra, it does so because it wants to support the arts, not because the arts represent a major part of their corporate revenue or earnings. Also, ultimately, expanding into Azerbaijan may be profitable.

From the perspective of the NGO, it may not make much difference why a firm chooses to form partnerships. Grants serve numerous purposes. First, they provide real support for needed programs and services. Just as important is the reality that such connections serve as symbolic recognition that the NGO is worthy of being supported. This, in turn, raises its domestic profile and may give it an advantage in seeking additional funds.

Ufug means 'horizon' in Azerbaijani. A horizon is more than just the point where the earth meets the sky. Often the horizon implies a goal, perhaps utopia, since it is always far off in the distance. Ufug is also the name of a nonprofit, non-governmental organization (NGO) whose mission is to help vulnerable children become healthy and real members of society (Ufug, 2009). Its success shows how dedicated individuals can work together in Azerbaijan to overcome financial, regulatory, and professional barriers.

Azerbaijan is transitioning from a centralized, government-dominated economy under the old Soviet system to a more internationally engaging, oil-based, (semi-) free trade system. This requires new legal, cultural, political, economic, fiscal and educational models. The biggest transition may have been between generations. The older population only knew the Soviet approach to things; i.e., the government controlled, the government provided, the government created, and the government ruled.

The post-Soviet generation is now graduating from college and has been adopting more Western style approaches in which individual merit can lead to success. One may succeed, or fail, based on hard work and appropriate risk-taking. It is acceptable (within bounds) to challenge central authority and traditional ways of doing things. Part of the new Azerbaijan is characterized by a growing the nonprofit sector. Local communities and individuals are allowed, and in some cases encouraged, to form NGOs for specific purposes. While the government sometimes appears threatened by these new structures, they form the backbone of developing democracies and civil societies.

\section{BUILDING A CIVIL SOCIETY}

Societies develop over time through customs, norms, laws, and economic decisions and they face numerous trials, wars, disasters and successes. Creating and then maintaining a civil society requires time, patience and many small efforts to create the whole. The World Bank's (2007) expansive definition of a 'civil society' includes 'the wide array of non-governmental and not-for-profit organizations that have a presence in public life, expressing the interests and values of their members, or others, based on ethical, cultural, political, scientific, religious or philanthropic considerations. ... [such as] community groups, non-governmental organizations (NGOs), labor unions, indigenous groups, charitable organizations, faith-based organizations, professional associations, and foundations." The following sections of this article show how these institutions are, and are not, forming in postSoviet Azerbaijan.

"Civil society generally consists of organizations that fall between the family and the state. A civil society is characterized by active, diverse, inclusive citizen participation" (United States Peace Corps (2007, p. 29). Providing these services and programs often fills important gaps that a government cannot (or will not) provide and that are beyond the means of any one family to meet. Therein lies the threat. Sometimes governments prefer to operate in the dark. The concepts of transparency and sunshine are not part of their vocabulary and experience. In fact, the Soviet legacy is one of a strong central government that often ruled by law, force, regulation and fear.

"NGOs promote pluralism, diversity, and tolerance in society while protecting and strengthening cultural, ethnic, religious, linguistic, and other identities" (Peace Corps, op. cit., pp. 21-22). History shows how the Azeri ethnic identity continued despite being conquered and ruled by several other nations. "In 1828, the Russian Empire and Iran divided the Azerbaijani people between them, yet an independent Azerbaijani ethnic identity has continued to exist to the present day. The independence of the former Soviet republic of Azerbaijan has further reinforced their 
collective identity" (Harvard, 2003). This change can be seen across the country, especially when one realizes that the teaching of Russian in the schools has been replaced by Azeri language and literature.

Another example still festers in Azerbaian. Domestic politics enters the picture when the topic of Armenia arises. Armenia captured about $16 \%$ of the Azeri nation by force in 1991. This has implications for NGOs in Azerbaijan. An Armenian news website (Armtown.com, 2006) wrote that "The national Forum of NGOs of Azerbaijan has decided to keep back from cooperation with Armenian NGOs, Day.az reports. Azerbaijani NGOs are allowed to cooperate only with those Armenian non-profit organizations that recognize Azerbaijan's territorial integrity and consider Nagorno-Karabakh regulation only possible within the international law.”

NGO leaders often depend on multiple sources of revenue to fund their programs. Ufug's experiences in this regard are instructive. Since Ufug does not have a single sponsor, part of its success lies in generating support from international organizations. World Vision International, British Business Group and ISAR/Azerbaijan collaborate with Ufug to offer two programs: "Save the Foundlings" and "Rejected Foundlings Help Center." (Foundlings are abandoned children.) Another issue is the potential conflict the NGOs have with the same government that registers them. There are burdensome taxes levied on the funds an NGO receives from international corporations or foundations.

Some nonprofit organizations have been accused of 'creaming', a form of rationing where any organization chooses those patients, clients, individuals or groups which it believes have the greatest likelihood of successful outcomes. This is easily justified since no system can do everything and be everything to everyone. Limited resources require allocation decisions. Ufug's mission statement stresses the opposite: "We choose those children who are the most heavily ill" (Ufug, op cit).

Mission statements serve to guide organizational programs. Specific administrative actions include the mundane (opening bank accounts, forming alliances with other children's service agencies, public information efforts) as well as more aggressive initiatives (registration, placing children in hospitals, arranging medical care, including surgeries, and providing orphaned children with the needed psycho-social and physical support. Except when grants allow the administrative staff to be paid, they work pro bono (without compensation). On Azerweb (2007), Ufug's major organizational activity is defined as "income generation", which fits perfectly with its mission. Ufug does not provide needed health and medical services. It links children in need with providers and pays for (or offsets) the cost of care. In Sheki, a city located approximately 200 miles from the capital city of Baku, Ufug's collaboration with the Scottish Society of Azerbaijan helped establish a mobile clinic that has provided care to needy children.

Another characteristic of civil societies is that NGOs motivate citizens in all aspects of society to act, rather than depend on state power and beneficence. This poses problems in Azerbaijan. According to the International Center for Nonprofit Law (2007), two of the government's criteria for NGOs to be licensed and operate effectively are that they join with state bodies to resolve social problems and coordinate decisions regarding organization, program goals and methods of action.

The national government in Azerbaijan has generally taken a two-faced approach to NGOs. On one hand, they encourage formation of those groups that will promote economic and business development, yet NGOs may encounter seemingly insurmountable problems in achieving these objectives. For example, a key element in the registration process is meeting the government's requirement that non-governmental organizations (NGOs) register with the Ministry of Justice (Organization for Security and Co-Operation in Europe, 2007). This is not an easy process and many organizations never successfully complete the registration. Too often they yield to the pressure of delays and have their application denied, sometimes without explanation (Ritvo, 2009).

The act of registering is full of uncertainties and the Organization for Security and Cooperation in Europe (OSCE) (2003) reports that the Department of Registration of Legal Entities has a number of policy and procedural problems: 
- $\quad$ slow decision-making process with unclear rules

- $\quad$ issuing denials that are often not based on published criteria

- $\quad$ endless requests for more data, even if not mandatory or even available

- $\quad$ staff members' failure to follow published rules, regulations and procedures, relying rather on their own whims

- $\quad$ little or no public input into proposed rules or regulations

The OSCE report concludes, "In order for Azerbaijan to acknowledge the obligations that it undertook by signing the international and European human rights documents, it is incumbent upon the State to redefine its policy toward independent NGOs and ensure the full exercise of freedom of association through greater compliance with existing legislation".

A major role for many NGOs is to advocate for mechanisms by which governments and the market can be held accountable by the public. The available information seems to reverse this principle. This research concludes that the government is trying to hold NGOs accountable for operating within the government's guidelines for programs, services, funding, and even the registration process. An added problem is that local officials often have little interest in NGOs. "In most regions, local officials are not willing to cooperate with local NGOs. Local officials often attend only those events that are organized by pro-governmental NGOs... As there is no coordination between local NGOs, they often duplicate each others' ideas and projects" (The Azerbaijan Human Rights Foundation, 2007).

As one of the major funding streams of the Soros Foundation (2007), the Open Society Institute (OSI), a private operating and grant making foundation, aims to shape public policy to promote democratic governance, human rights, and economic, legal, and social reform. In sum, its goal is to create a civil society, with special attention to the post-Soviet states. Its work in Azerbaijan has helped many NGOs form, manage the registration process and provide needed services, as well as open the doors to international understanding among Azerbaijan's young adults through scholarships and other programs.

Most international philanthropy and funded programs now require accountability and transparency and the government of Azerbaijan has 'transparency' as one of its operating criteria for NGOs. Few would argue with the need for this, especially in a country that is known for corruption. According to the Transparency Index, Azerbaijan ranks $150^{\text {th }}$ out of 179 nations, below Russia, Libya and Uganda (Transparency International (2007). By comparison, the United Kingdom ranks 12th and the United States places 20th. International philanthropy has two major goals: 1) to fund needed programs so they can provide quality services in an effective and efficient manner and 2) to help NGOs sustain these efforts. In the post-Soviet era, the first goal is succeeding far more than the second. "Most regional NGOs are not transparent and are ruled in an authoritarian way" (Azerbaijan Human Rights Foundation, 2007).

The record of longevity for newly formed NGOs is less than impressive. According to the United Nations Development Report (2003), "Over the past years, there has been an intensive process of establishing NGOs in Azerbaijan. Their activities now cover most aspects of public life. Around 1,500 NGOs have been established. However, the lack of a general database on all the NGOs operating in the country prevents a complete understanding of all their activities." Without accountability, formal structures, government registration, and on-going financial support, they failed to survive beyond a few "good years (Tohidi, 2004).

Often, the citizens in Azerbaijan express skepticism about the true independence of the NGO. Looking back to the Soviet-dominated society, the historic view remains that largesse came from, or through, the central government. Since this reflects a European perspective as well, it is understandable. The alternative view is more common in the United States where NGOs must raise their own funds, some of which come from the government. While these are often program-specific contracts, that distinction gets lost in the broader conversation. The Azeri experience reflects neither polarity. The NGOs need funds to start and maintain their operations, yet government does not view them as filling service gaps or citizen needs. They suspect that many NGOs are pushing for greater governmental transparency in systems that are not accustomed to such candor. 
Finally, since the government remains a central force in the existence and work of NGOs, it is important to assess this relationship. Fear and distrust of the government remain high. "While the government insists its aim is to increase funding for NGOs, some activists are fearful that the real intention is to impose control over their work." .... "But critics of the [international philanthropy] fear it is designed to counteract the influence of foreign donors and the NGOs they fund - many of which are strongly critical of the government's policies and record on human rights" (Institute for War \& Peace Reporting, 2007).

The International Center for Nonprofit Law (2007) also notes that the government has its own principles regarding NGOs. These were not developed jointly or in consultation with the non-governmental sector. In fact, Presidential decrees define changes in government policy and are often just announced.

One of the elements of the civil society movement is the empowerment of the population. In Azerbaijan today, women's roles are limited, although this is changing. Limitations come from history, tradition, and religious beliefs (Azerbaijan is about 96\% Muslim, even though the Soviets prohibited religious practices). Thus, the development of civil society's institutions fits perfectly with the expanding and changing role of women "because NGOs are busy addressing many of the social problems that women have been left to address for years - disabilities, health, children's issues and education" (Tohidi, 2004).

\section{WORKING WITH NGOs}

Based on this research, there are several guidelines and actions that corporations should consider as they expand into Azerbaijan:

1. Select carefully - Corporate decision-makers must be clear on why their firm wants to work with NGOs. There are numerous positive reasons for so doing, ranging from a desire to help, to the bottom line, to its corporate social responsibility.

2. Due diligence works - As with all investments of a firm's resources (money, time, reputation), it pays to do one's homework. Meet with the NGO's top leadership, tour the facilities, and talk to clients or patrons. The axiom is true - one can see a lot by observing!

3. Demand periodic reports - Most NGOs, and all reputable NGOs, will expect a corporation to request more than just an annual report. Just asking for receipts is not enough. The philanthropy or corporate finance department should receive periodic (quarterly?) reports on both expenditures and progress toward stated goals, objectives, programs and services. This principle was clearly delineated in a letter regarding British firms' support of various NGOs in Azerbaijan: "As Board members, we will watch closely to ensure that both these procedures are followed and, should support be agreed, that management continues to keep the Boards informed during implementation." (BTC, 2005)

4. Patience is a virtue - In Azerbaijan, like other developing countries, the old ways often frustrate contemporary demands. The Western idea of things happening on-time, in-time, or in-no-time seems overly aggressive and is often disrespectful in other societies. Most corporations have learned that longterm success comes from adapting, as needed, to local laws, customs, mores and traditions. Working with NGOs should follow these lessons.

5. Avoid the appearance of corruption - Unfortunately, corruption is still prominent in Azerbaijan. Gift giving, employing friends and family, or straight-out bribes are part of the lingering legacy of Soviet domination. Walk away if there is the slightest hint that inappropriate actions are expected; and remember that as an international visitor, their laws apply.

6. Decide whether your firm can support non-registered NGOs - It is often difficult for developing NGOs to meet governmental registration standards. This does not mean that the NGO is not worth supporting. It might mean that they are seen as a threat to the status quo. For example, advocates for women's empowerment have experienced difficulty registering their NGOs because of the perceived threat to husbands' domestic rights (Tohidi, 2004).

7. Demand Transparency - This could be the first rule as its basic principles form the foundation for longterm relationships or short-term disasters. The giving organization should be transparent in its financial transactions in Azerbaijan and the receiving partner NGO must be transparent in its work. Opaque transactions increase the risk of professional, legal and political problems. There is a good reason why the 
demand for transparency crosses international borders - Secrecy leads to suspicion and suspicion results in failure.

\section{CONCLUSION}

Oil fuels the economic engine of $21^{\text {st }}$ century Azerbaijan. It has transformed the physical structure of the country. Its reach into the rural areas has added employment in areas that were neglected in the past, and it has brought international attention and new organizational forms. The fundamental questions center on how successful NGOs can be if the governmental mistrust continues. NGOs form the heart of an open, civil and transparent society, yet much of the progress of the past decade is threatened. "Controversial amendments that would impose new restrictions on non-governmental organizations could force numerous local and international NGOs in Azerbaijan to cease operation. Some activists go so far as to say the amendments, if passed, would throttle civil society development in the country" (Hayden, 2009)

International firms will continue to expand into Azerbaijan as long as it is in their corporate interest to do so, and it is in their strategic business interest to remain friendly with the government, as well as the Azeri people. Why? The answer is simple, clear and persuasive - NGOs and civil societies "remain compelling because [they] speak to the best in us - the collective, creative and values-driven core of the active citizen, calling on the best in us to respond in kind to create societies that are just, true and free". (Edwards, 2007)

\section{AUTHOR INFORMATION}

Roger A. Ritvo, Ph.D. is a Distinguished Research Professor of Management at Auburn University Montgomery (Alabama). As a Fulbright Scholar, Professor Ritvo taught in Azerbaijan for the fall semester, 2006 and returned to continue field research in November 2007. The Auburn University Montgomery Research Council partially supported this project. His latest book is Nonprofit Organizations: Principles and Practices (with T. Holland) published by Columbia University Press. Dr. Ritvo has served as a college dean (University of New Hampshire) and Vice Chancellor of Academic \& Student Affairs (Auburn University Montgomery).

\section{REFERENCES}

1. American Petroleum Institute (2007). Fact Sheet: Exxon/Mobil. http://www.api.org/ehs/partnerships/viewcompany/exxonmobil.cfm. Accessed December 9, 2007.

2. $\quad$ Armtown.com (2006). Bad News for Grant-Dependent NGOs. April 29, 2006. http://www.armtown.com/news/en/azg/20060429/2006042906. Accessed December 8, 2007.

3. Azerbaijan Human Rights Foundation (2007). http://mill-az.org/index.php?page=project_history. Accessed December 8, 2007.

4. Azerweb (2007). http://www.azerweb.com/en/ngo.php?id=376. Accessed December 7, 2007.

5. BTC, 2005. www.ecgd.gov.uk/btcletter.doc. Accessed June 19, 2009.

6. de Tocqueville, A. (1904). Democracy in America, translated by Harry Reeve, Appleton \& Co., New York.

7. $\quad$ Edwards, M. (2004). Civil Society. Polity Press, Cambridge.

8. Edwards, M. (2007). "Love, Reason and The future of Civil Society," in L. McIlrath and I. MacLabhrainn (eds), Higher Education and Civic Engagement: International Perspectives. Ashgate Publishing, Ltd., London.

9. Institute for War \& Peace Reporting (2007). “Azeri Government Launches NGO Programme, Caucasus Reporting Service,” CRS No. 414 11-Oct-07. Accessed December 8, 2007. http://iwpr.net/?p=crs\&s=f\&o=339798\&apc state=henpcrs

10. Harvard (2003). Kennedy School Bulletin "InPrint," Accessed December 8, 2007. http://www.ksg.harvard.edu/ksgpress/bulletin/spring2003/charles/in_print.html.

11. Hayden, Jessica. “Azerbaijan: NGO Amendments Put Civil Society At Risk.” EurasiaNet.org June 17, 2009. Accessed June 18, 2009. http://www.eurasianet.org/departments/insightb/articles/eav061709.shtm

12. Independent Sector (2007). www.independentsector.org/about/index.html. Accessed December 12, 2007

13. International Center for Nonprofit Law (2007). Accessed December 8, 2007. http://www.icnl.org/knowledge/news/2007/11-19_Decree.pdf 
14. Organization for Security and Co-Operation in Europe (2007). Office for Democratic Institutions and Human Rights. LegislatiOnLine: Azerbaijan. http://www.legislationline.org/?tid=220\&jid=6\&less=false. Accessed December 8, 2007.

15. Organization for Security and Co-operation in Europe (2003). Problems of NGO Registration in Azerbaijan - a Survey. Summary of Findings. www1.osce.org/documents/ob/2003/08/558_en.pdf. Accessed December 8, 2007.

16. Peace Corps (2007). An NGO Training Guide for Peace Corps Volunteers: Module One:

17. The Role of NGOs in a Civil Society. Washington, DC, pp. 21-22. Accessed December 7, 2007. http://www.peacecorps.gov/multimedia/pdf/library/M0070_mod1.pdf

18. Peterson, T. J. and Van Til, J. (2004). Defining Characteristics of Civil Society, The International Journal of Not-for-Profit Law, 6:2, January 2004.

19. Publishwhatyoupay.com (2009). Stealth oil agreements threaten Azerbaijan's reputation and policy progress. Web site accessed June 16, 2009. http://www.publishwhatyoupay.org/en/resources/stealth-oilagreements-threaten-azerbaijans-reputation-and-policy-progress

20. Putnam, Robert. D. (2000). Bowling Alone: The collapse and revival of American community, Simon and Schuster, New York.

21. Ritvo, Roger A. "Making a Difference With and Without Government Support: The Mission of NGOs in Post-Soviet Azerbaijan," Journal of Leadership, Accountability and Ethics, pp. 30-44, Winter 2009.

22. Rainovosti (2009). Azerbaijan plans to develop oil fields in Cuba. May 19, 2009. http://en.rian.ru/business/20090519/155042671.html

23. Soros Foundation (2007). http://www.soros.org/about, Accessed December 12, 2007.

24. Tohidi, N. (2004). Women, Civil Society, and NGOs in Post-Soviet Azerbaijan, International Journal of Not-for-Profit Law, 7:1, November 2004. http://www.icnl.org/knowledge/ijnl/vol7iss1/special_4.htm. Accessed December 8, 2007.

25. Transparency International (2007). Corruption Perception Index, 2007. Accessed December $12,2007$. http://www.transparency.org/policy_research/surveys_indices/cpi/2007

26. Ufug (2009). Web site home page. http://www.azerweb.com/en/ngo.php?id=376. Accessed June 16, 2009.

27. United Nations Development Report (2003). Modern Technologies and the Democracy Process. Chapter 4; Section 4.5. ICTs and Strengthening the Role of NGOs. Azerbaijan Human Development Report 2003. http://www.un-az.org/UNDP/nhdr2003/45.html. Accessed December 7, 2007.

28. Wall Street Journal, June 16, 2009. http://online.wsj.com/article/BT-CO-20090616-708699.html

29. World Bank (2007). Civil Society Web page Accessed December 9, 2007 http://web.worldbank.org/WBSITE/EXTERNAL/TOPICS/CSO/0,,contentMDK:201014 menuPK:244752 $\sim$ pagePK:220503 piPK:220476 theSitePK:228717,00.html

30. World Bank (2008). Doing Business: Country Profile: Azerbaijan, 2009. Accessed June 16, 2009. www.doingbusiness.org/Documents/CountryProfiles/AZE.pdf.

31. World Vision International (2007). Web site home page Accessed December 8, 2007. www.wvi.org. 
International Journal of Management \& Information Systems - First Quarter $2011 \quad$ Volume 15, Number 1 NOTES 